\title{
Addressing Overlapping Migratory Categories within New Patterns of Mobility in Peru
}

\author{
Cécile Blouin and Emily Button
}

\begin{abstract}
This article reflects on the construction and application of different migratory categories in the Peruvian context, including irregular migrants, refugees, victims of trafficking, and smuggled migrants. Through legal analysis and interviews with key migration actors in the country, the paper explores the ways in which Peru responds to migrants in these different categories, in view of the recent changes in human mobility in the country. The article aims to shed light on the fragmentation of migratory categories and the negative effects this has on migrants' human rights. It is exploratory in nature and serves as a starting point for further debate on the subject.
\end{abstract}

Keywords: trafficking in persons, irregular migration, migrant smuggling, refugees, Peru, categorisations

Please cite this article as: C Blouin and E Button, 'Addressing Overlapping Migratory Categories within New Patterns of Mobility in Peru', Anti-Trafficking Review, issue 11, 2018, pp. 69-84, www.antitraffickingreview.org

This is an open-access article distributed under the terms of the Creative Commons Attribution License (CC-BY). Under the CC-BY license, the public is free to share, adapt, and make commercial use of the work. Users must always give proper attribution to the authors and the Anti-Trafficking Review. 


\section{Introduction}

Migratory patterns affecting Peru have changed drastically since 2017, with the country becoming the main destination for Venezuelan migrants. ${ }^{1}$ The human rights situation in Venezuela has been deteriorating since 2015, including limitations on freedom of speech, an increase in crime rates and severe shortages of food and health services. As a result, large numbers of Venezuelans have been forced to migrate to other countries. ${ }^{2}$ Between January and September 2017, 103,000 Venezuelans crossed the Peruvian border in Tumbes, an average of about 381 migrants a day. ${ }^{3}$ In early 2018, their numbers further increased to 1,000 daily entries. ${ }^{4}$ Peru's government agencies have been overwhelmed with this influx, given their limited financial and human resources.

Peru is also facing challenges in identifying and protecting foreign victims of human trafficking. In 2016, the National Police registered 1,846 trafficked persons in the so-called Sistema RETA. ${ }^{5}$ However, this information is not disaggregated by nationality and only includes cases where charges have been filed against alleged perpetrators. In general, foreign victims of human trafficking are rarely identified in Peru; instead, they are typically treated as irregular migrants and deported back to their countries of origin. ${ }^{6}$

1 UNHCR, Operational Portal, Refugee Situations, Venezuela Situation, retrieved 07 March 2018, https://data2.unhcr.org/en/situations/vensit.

2 Inter-American Commission on Human Rights, 'Situation of Human Rights in Venezuela', OEA/Ser.L/V/II, Doc. 209, 31 December 2017, retrieved 7 March 2018, http://www.oas.org/en/iachr/reports/pdfs/Venezuela2018-en.pdf.

3 International Organization for Migration, Matriz de Seguimiento de Desplazamiento (DTM) - OIM Perú Ronda I, Octubre-Noviembre 2017, retrieved 22 March 2018, https:// reliefweb.int/report/peru/flujo-de-migraci-n-venezolana-1-octubrenoviembre- 2017.

4 UNHCR, Situational Update, Venezuela Situation, January 2018, retrieved 7 March 2018, https://data2.unhcr.org/en/documents/download/62291.

5 Defensoría del Pueblo de Perú, Trata de Personas con Fines de Explotación Sexual en agravio de mujeres adultas, October 2017, retrieved 8 March 2018, http:// peru.unfpa.org/sites/default/files/pub-pdf/I.A-041-2017-ADM-trata-demujeres $\% 281 \% 29$.pdf. The RETA is the Registry and Statistical System of Trafficking in Persons and Related Crimes of the National Police of Peru (PNP).

6 Women's Link Worldwide, Victimas de Trata en América Latina entre la desprotección y la indiferencia, WLW, 2017, p. 28. 
Against this backdrop, this article reflects on the construction and application of different categories surrounding human mobility in Peru. Given that very few analyses exists on the current Peruvian migratory context, the paper is exploratory in nature; it does not aim to draw any definitive conclusions, but rather to serve as a starting point for further research. In particular, the article discusses how relevant state actors conceptualise and respond to the categories of irregular migrants, smuggled migrants, victims of human trafficking and asylum seekers, and identifies key shortcomings and their repercussions for the migrants affected.

The paper derives its arguments based on a bibliographic review of academic materials, reports to the Committee on the Protection of the Rights of All Migrant Workers and Members of their Families (CMW), ${ }^{7}$ other publications from civil society, governmental or international organisations, and inputs from the principal actors working on migration in Peru. The latter were sought through a focus group discussion involving the International Organization for Migration (IOM) and the National Superintendence of Migration (MIGRACIONES), and individual interviews with six people from three public institutions - the Special Commission for Refugees of the Ministry of Foreign Affairs, the Ministry of the Interior, and the Ombudsman's Officeone international organisation, the United Nations High Commissioner for Refugees (UNHCR), and one civil society organisation, Encuentros Jesuit Service of Solidarity. ${ }^{8}$ The questions revolved around the identification of cases and the difficulties related thereto, the possible overlaps in categories and the responses of the state to this reality.

The last report was coordinated by the Institute for Democracy and Human Rights at the Pontifical Catholic University of Peru (IDEHPUCP). It identified a series of problems related to the deprivation of liberty of asylum seekers, who were allegedly being smuggled into the country. The findings in this report were driving factors in the decision to further investigate and analyse the issue of categorical overlaps in the Peruvian context.

8 We had originally planned to conduct a focus group discussion with all relevant actors, but due to scheduling conflicts only two institutions (IOM and MIGRACIONES) were able to attend the meeting. We then organised key informant interviews with most of the remaining actors, but were unable to arrange a meeting with an NGO that works with victims of trafficking. 


\section{Conceptual Framework}

\section{The construction of migrant categories - Theory vs. reality}

Categories applied to migrants have significant impact and result in vastly different responses to the individuals concerned. As Erdal and Oeppen point out, 'Whether someone is discursively presented as an economic migrant or a refugee, for instance, majorly influences their treatment by immigration authorities and humanitarian actors." It is thus important to scrutinise the conceptualisation and application of such categories, especially given that migration is complex and a migrant's motives for leaving a country are varied and may change over time.

A narrow construction of grounds for protection can fail to take into account the fluid nature of migrants' journeys and may lead to infringements of their human rights. Indeed, legislation on asylum in many countries across world regions, including Europe and Latin America, primarily focuses on the concept of persecution, thereby excluding migrants fleeing natural disasters or dire economic conditions. As Zetter notes, the 'causes and patterns of forced migration...are much more complex than in the past.... In complex emergencies many people are caught up in conflict and flee, though they are not persecuted. ${ }^{10}$ For example, a study on Syrian migrants in Europe found that many had decided to move for economic reasons, and not necessarily for fear of persecution. The ongoing conflict in the country had destroyed businesses and forced them to move because no more work was available. ${ }^{11}$ Further, many trafficked persons begin their journeys as voluntary migrants who use the services of smugglers to enter a country before falling into conditions of severe exploitation. ${ }^{12}$

9 M B Erdal and C Oeppen, 'Forced to Leave? The discursive and analytical significance of describing migration as forced and voluntary', Journal of Ethnic and Migration Studies, vol. 44, no. 6, 2018, pp. 981-998, p. 983.

10 R Zetter, 'More Labels, Fewer Refugees: Remaking the refugee label in an era of globalization', Journal of Refugee Studies, vol. 20, no. 2, 2007, pp. 174-176.

${ }_{11}$ H Crawley and D Skleparis, 'Refugees, Migrants, Neither, Both: Categorical fetishism and the politics of bounding in Europe's "migration crisis", Journal of Ethnic and Migration Studies, vol. 44, no. 1, 2018, pp. 48-64, p. 53.

12 M McAdam, 'Who's Who at the Border? A rights-based approach to identifying human trafficking at international borders', Anti-Trafficking Review, issue 2, 2013. 
The flaws of distinguishing between forced and economic migrants are also evident with respect to Venezuelans in Peru. A recent report by the IOM found that 67.5 per cent of them identified economic or employment factors as the principal reasons for leaving their country. ${ }^{13}$ These, however, need to be seen in light of the political climate that contributed to the economic collapse in Venezuela and the resulting job shortage-factors so relevant that UNHCR has called on states to ensure that they uphold the principle of non-refoulement with respect to Venezuelans, consistent with international refugee and humanitarian law. ${ }^{14}$

Such examples demonstrate that 'the decision to leave can only be understood within a wider political economy of forced migration rather than as a response to individualised threats of violence'. ${ }^{15}$ Ignoring or slighting such broader conditions underpinning migration leads to an over-reliance on legally established categories. This has been identified as a fundamental weakness in refugee studies, as it 'limits the extent to which research can offer a radical analysis of the situation of forced migrants that may bring substantive change to their lives'. ${ }^{16}$

\section{Reimagining migrant categories}

Categorising migrants and migration is inevitable; categories 'are the most rudimentary tools in any attempt at generalisation to offer an explanation of migration... [and are] central to processes of social control'; ${ }^{17}$ they are political, open and fluid, rather than fixed, closed constructs. ${ }^{18}$

13 International Organization for Migration.

14 UNHCR, 'Guidance Note on the Outflow of Venezuelans', March 2018, retrieved 22 March 2018, http://www.refworld.org.es/cgi-bin/texis/vtx/rwmain/ opendocpdf.pdf? reldoc $=\mathrm{y} \&$ docid $=5 \mathrm{aa} 07 \mathrm{abd} 4$.

15 Crawley and Skleparis, p. 55.

16 O Bakewell, 'Research Beyond the Categories: The importance of policy irrelevant research into forced migration', Journal of Refugee Studies, vol. 21, issue 4, 2008, pp. 432-453, p. 437.

17 M Collyer and H de Haas, 'Developing Dynamic Categorisations of Transit Migration', Population, Space and Place, vol. 18, issue 4, 2012, pp. 468-481, p. 468.

18 R Jones, 'Categories, Borders and Boundaries', Progress in Human Geography, vol. 33, issue 2, 2009, pp. 174-189, pp. 175, 186. 
As illustrated above, however, the current international legal framework fails to take into account that a person may fall into different migrant categories at different times in the journey, or at the same time. It is therefore important to deal with migrants through the perspective of human rights, ensuring that those in need receive the minimum protections they are entitled to, irrespective of rigid classifications.

Beyond that, it is vital to approach categorisation in a holistic manner and recognise potential overlaps. For example, trafficked persons may be refugees and vice versa; this means that the individuals affected are entitled to the full range of protections and services afforded by both frameworks, as recognised in the relevant international instruments. ${ }^{19}$

\section{International and Peruvian Legal Framework}

Such categorisations in international law are also reflected in the Peruvian context. Whilst the country has introduced a number of acts for the protection of migrants, trafficked persons and others, these generally operate separately and their application remains challenging, as our analysis shows.

In 2017, Peru passed a new general migration law (Legislative Decree 1350), which aligns the country's migration policy with international law and recognises several fundamental rights of migrants, such as access to basic health services, education and justice mechanisms. ${ }^{20}$ Further, the regulation operationalising the law has introduced a series of protections for vulnerable migrants, including victims of domestic and sexual violence, trafficked persons and smuggled migrants, irregular migrants, elderly people, indigenous and tribal people, and LGBTI people, among others. ${ }^{21}$

19 A Gallagher, The International Law of Human Trafficking, Cambridge University Press, New York, 2010, pp. 197-198.

20 Decreto Legislativo No. 1350; Decreto Supremo No. 007-2017-IN.

21 Decreto Supremo No. 007-2017-IN, Art. 227. 
Peru has also taken steps to formalise the status of irregular migrants. Legislative Decree 1350 establishes a humanitarian migration visa (calidad migratoria humanitaria) to be issued by the Ministry of Foreign Affairs, which will be available to extremely vulnerable migrants, including asylum seekers and victims of human trafficking or migrant smuggling. ${ }^{22}$ However, the new humanitarian visa is not yet effective as it lacks the administrative regulation necessary for implementation. The same law further establishes a special migration visa (calidad migratoria especial) requiring authorisation by MIGRACIONES. This visa is extended in exceptional circumstances to foreigners in vulnerable situations, ${ }^{23}$ including — as per a recent directive of MIGRACIONES — victims of trafficking in persons and smuggled migrants. ${ }^{24}$ The groups covered by the humanitarian migration and the special migration visas therefore overlap. The latter, however, does not require additional administrative regulations for implementation and has already been utilised in emergency situations where migrants were in need of protection. ${ }^{25}$

Further, a Temporary Stay Permit (Permiso Temporal de Permanencia or PTP) has been introduced for vulnerable migrants before they receive a special migration visa. Three PTP windows have been opened by the government to date in an attempt to manage the recent influx of Venezuelan migrants to the country. The current PTP process allows Venezuelans who enter the country through

22 Ibid., Art. 29.2(k).

23 Ibid., Art. 230.1 and 230.2.

24 Superintendente Nacional, Resolución de Superintendencia No. 0000357-2017Migraciones, Aprueban la Directiva 'Atención a Victimas de trata de Personas y Tráfico Ilícito de Migrantes', 28 de diciembre de 2017, retrieved 19 March 2018, http:// busquedas.elperuano.pe/normaslegales/aprueban-la-directiva-atencion-a-victimasde-trata-de-perso-resolucion-n-0000357-2017-migraciones-1602482-1/.

25 IDEHPUCP, Informe Alternativo al Comité de Protección de los Derechos de Todos los Trabajadores Migratorios y de sus Familiares Perú, 11 November 2017, p. 13, retrieved 22 March 2018, http://cdn01.pucp.education/idehpucp/wp-content/uploads/ 2017/09/11234252/11-09-final-informe-alternativo-al-comite-de-protecciontrabajadores-migratorios.pdf. 
31 December 2018 to apply for a Temporary Stay Permit. ${ }^{26}$ The PTP is different from other visas because it is targeted at a particular situation and does not grant residency.

Moreover, Peru is party to the 1951 Convention Relating to the Status of Refugees and its 1967 Protocol, and has adopted the expanded definition of the Cartagena Declaration on Refugees, which includes protection in cases of foreign aggression, internal conflicts, severe violations of human rights or other circumstances that have seriously disturbed public order. ${ }^{27}$ Law No. 27891 establishes that, once refugees are recognised as such by the state, they have the same rights and obligations that the Constitution and laws confer on foreign residents. It also stipulates that the Special Commission for Refugees (the main body charged with processing refugee applications) will provide assistance programmes for their integration, resettlement or repatriation. ${ }^{28}$ Whilst there is currently no national plan with respect to refugees, in 2018 the country passed a National Plan on Human Rights, which, among other objectives, aims to guarantee that refugees have access to programmes facilitating their integration and to ensure that asylum seekers are granted emergency health care. $^{29}$

26 Decreto Supremo No. 001-2018-IN Aprueban lineamientos para el otorgamiento del Permiso Temporal de Permanencia para las personas de nacionalidad venezolana. Further, within 24 hours of enacting the latest authorisation of the PTP, 1,700 appointments for obtaining such status had been registered online (UNHCR, Situational Update, Venezuela Situation, January 2018, retrieved 7 March 2018, https://data2.unhcr.org/en/documents/download/62291). It is important to mention that this is the third PTP for Venezuelans approved since 2017: DECRETO SUPREMO No. 002-2017-IN (publicado el 3 de enero de 2017) and DECRETO SUPREMO No. 023-2017-IN (publicado el 29 de julio de 2017). Note that the state has also introduced Temporary Stay Permits for other groups, such as mothers or fathers of permanently disabled minor or adult children of Peruvian nationality (see: Decreto Supremo No. 001-2017-IN Lineamientos para el Otorgamiento del Permiso Temporal de Permanencia para las Personas Extranjeras Madres o Padres de Hijos/as Peruanos/as menores de edad e hijos/as mayores de edad con discapacidad permanente).

27 Colloquium on the International Protection of Refugees in Central America, Mexico and Panama, Cartagena Declaration on Refugees, 22 November 1984, part III, para. 3.

28 Ley No. 27891 (Ley del Refugiado), 20 December 2002, Art. 3.

29 Plan Nacional de Derechos Humanos 2018-2021, p. 144 (approved through Supreme Decree 002-2018-JUS). 
Further, the Peruvian definition of human trafficking as contained in Law No. 28950 is largely aligned to that of the UN Trafficking Protocol. The act and its administrative regulation also establish that the state will provide victims with safe repatriation and various other services such as temporary accommodation, and medical, psychological, social and legal assistance. In addition, the National Plan against Trafficking in Persons (2017-2021) sets forth measures to guarantee care for victims of trafficking, including safeguards for the protection of children and adolescents. ${ }^{30}$ Except in referencing the humanitarian migration visa, however, it does not deal with the particular situation of foreign trafficked persons, their identification and reintegration. Instead, trafficking victims from abroad are more specifically included under the separate National Policy against Trafficking in Persons and Its Attendant Forms of Exploitation. Introduced in 2015, the policy's general guidelines require that the state strengthen the comprehensive care and protection of national and foreign trafficked persons, and ensure coordinated and concerted action by all agents through immediate and appropriate multisectoral assistance. ${ }^{31}$ However, the National Policy, unlike the National Plan, does not establish indicators for monitoring the progress of its implementation.

Peru is also party to the Protocol against the Smuggling of Migrants by Land, Sea and Air, which stipulates that migrants not be liable to criminal prosecution for having been smuggled. ${ }^{22}$ The Protocol further provides that states must take measures to afford migrants appropriate protection against violence, and to assist those whose lives or safety have been endangered by reason of having been smuggled. ${ }^{33}$ It is important to note that the Protocol refers to smuggled migrants as 'objects of the offence', rather than 'victims of the offence', on the premise that they consent to being smuggled and should thus only be considered victims if they suffer other crimes in the process, such as kidnapping or physical violence. ${ }^{34}$ Peruvian legislation applies a more generous approach.

30 Decreto Supremo No. 017-2017-IN Decreto Supremo que apruebael Plan Nacional contra la Trata de Personas 2017-2021.

31 Ministry of Justice, Decreto Supremo No. 001-2015-JUS, Aprueban Política Nacional frente a la Trata de Personas y sus formas de explotación.

32 UN General Assembly, Protocol Against the Smuggling of Migrants by Land, Sea and Air, Supplementing the United Nations Convention Against Transnational Organized Crime, 15 November 2000, Art. 5.

33 Ibid., Art. 16.

34 C Blouin, 'La Normativa Peruana en Materia de Tráfico de Migrantes a la Luz del Derecho Internacional: ¿Hacia una protección de los derechos de las personas migrantes?', Revista Espiga, vol. 17, no. 34, 2017, pp. 215-230. 
The country's immigration law (Legislative Decree 1350) speaks of 'victims of smuggling', and Law No. 28950 and its administrative regulations grant smuggled migrants, children and pregnant women the right to assistance from the state. ${ }^{35}$ However, the country is lacking a national plan on migrant smuggling and separate guidelines for identifying and providing assistance to smuggled migrants, although some coverage is provided through the national human rights protection framework. ${ }^{36}$

\section{Key Problems in the Application of Migrant Categories in Peru}

\section{Cases of overlapping categories}

Through both primary and secondary research for this paper, we have identified two instances of overlapping migratory categories in the Peruvian context: between smuggled migrants and asylum seekers, and between foreign trafficked persons and irregular migrants.

According to the Ministry of Foreign Affairs and information shared in the Inter-Sectoral Working Group for Migration Management, ${ }^{37}$ authorities have observed migrants arriving at the Jorge Chávez International Airport in Lima via smuggling networks and then applying for refugee status to enter the country, as advised by their smugglers. ${ }^{38}$ Once in Peru, they reportedly disappear and never formalise their claims. In response, the state has decided to deny asylum seekers entry and to process refugee claims at the airport, arguing that most applications for asylum turn out to be unfounded. A report documenting such cases found that, from 2015 until the first half of 2017, twenty-one asylum seekers, including two girls, were detained at the airport for periods between four and twenty days. ${ }^{39}$ This practice contravenes key standards in

35 Decreto Supremo No. 001-2016-IN, Art. 50.1.

36 Plan Nacional de Derechos Humanos 2018-2021, p. 144.

37 IDEHPUCP participated in the meeting of 26 June 2017 in which this problem was presented by the Ministry of Foreign Affairs and MIGRACIONES.

38 We do not have precise information about the cases. Apparently, in some cases migrants did not have the required visa and in others they had a forged document. It has not been confirmed whether the smugglers accompanied the migrants on their journey.

39 IDEHPUCP 2017, pp. 15-17. 
protecting the rights of migrants ${ }^{40}$ and is particularly worrying as it concerns applicants for refugee status. ${ }^{41}$ In this case, it appears that the state is applying the less protective category of smuggled migrant over that of asylum seeker.

Further, according to the latest figures published by the NGO CHS Alternativo, ten foreign trafficked persons were identified in the Sistema RETA in the first half of $2017,{ }^{42}$ while MIGRACIONES reported that it dealt with four cases of human trafficking in all of 2017. ${ }^{43}$ MIGRACIONES has also granted a first-ever special migration visa to a foreign trafficked person ${ }^{44}$ and, aware that there are more such cases, expects the numbers to increase following more concerted state efforts to implement the National Plan against Trafficking in Persons. $^{45}$

In both cases, the misapplication of migratory categories and the negative repercussions for the individuals concerned appear rooted in two key factors: the fragmentation of institutional mandates and the lack of regulations for policy implementation.

40 General Comment No. 2 on the rights of migrant workers in an irregular situation and members of their families raised by the Committee on the Protection of the Rights of All Migrant Workers and Members of their Families (CMW), retrieved 13 August 2018, http://www2.ohchr.org/english/bodies/cmw/docs/ CMW_C_GC_2_ENG.PDF.

41 The 1951 Refugee Convention, in its article 31, prohibits sanctions such as detention, imposed on refugees only because of their illegal entry or presence.

42 Capital Humano y Social Alternativo, V Informe Alternativo Principales Hallargos 2016-2017 Balance de la sociedad civil sobre la situación de la trata de persona en el Perút 2016-2017, CHS Alternativo, Lima, 2017, p. 28, retrieved 13 August 2018 http:// chsalternativo.org/balances-e-informes-alternativos/669-principales-hallazgos-delv-informe-alternativo-2016-2017/file.

43 Superintendencia Nacional de Migraciones, Presencia de Inmigrantes en Situación de Vulnerabilidad en el Perú. Estudio preliminar realizado desde una perspectiva de género, 2018, retrieved 19 March 2018, https://www.migraciones.gob.pe /wp-content/uploads/2018/03/Presencia_inmigrantes_situacion_vulnerabilidad_Peru.pdf. We cannot say if these four cases are included in the ten cases recorded by RETA in the first half of 2017 because registrations of trafficking cases by different agencies are not crosslinked. See: Mac Gillivray et al., Manual de Capacitación para Operadores de Justicia Durante la Investigación y el Proceso Penal en Casos de Trata de Personas, IDEHPUCP, Lima, 2017, p. 23.

44 Superintendencia Nacional de Migraciones, 2018.

45 Ibid., p. 31. 


\section{Fragmentation of institutional mandates}

In Peru, different government institutions are responsible for different categories of migrants, resulting in a fragmented response to migration. The Ministry of the Interior deals with human trafficking and migrant smuggling, the Ministry of Foreign Affairs is in charge of asylum claims, ${ }^{46}$ and MIGRACIONES oversees broader immigration matters. The 'Vulnerability Office' created by MIGRACIONES in 2016 is the only institution charged with an integrated approach to vulnerable migrants ${ }^{47}$ and as such may have contact with the entire migrant population (including victims of human trafficking, refugees and smuggled migrants).

However, a representative of MIGRACIONES highlighted in our meeting that '[the agency] has not been seen by [other institutions] as a key actor in the area of trafficking in persons; the victim assistance framework does not include the MIGRACIONES office' (translation by the authors). The exclusion of MIGRACIONES from cases involving potential foreign victims of trafficking means that the individuals concerned cannot receive a residence permit and remain therefore excluded from some of the protections offered by the state, in particular from health, education and most other governmental services. In other words, the fragmentation of institutional mandates and the resulting lack of cooperation between state agencies mean that foreign victims of trafficking are treated as irregular migrants rather than victims.

Moreover, whilst there are two inter-institutional mechanisms seeking to facilitate coordination, namely the Inter-Sectoral Working Group for Migration Management ${ }^{48}$ and the Permanent Multisectoral Commission against Trafficking in Persons and the Illicit Smuggling of Migrants (CMNP TP-

46 Decreto Supremo N 135-2010-RE, Reglamento de Organización y Funciones del Ministerio de Relaciones Exteriores, 18 December 2010, Art. 99.

47 Superintendencia Nacional de Migraciones 2018, pp 11-12. According to an interview we conducted with an official of the Vulnerability Office, the creation of a Sub-Directorate of Migration Integration is pending, which will seek to support migrants in Peru, especially those in vulnerable situations.

48 Decreto Supremo no 067-2011-pcm, Crean la Comisión Multisectorial Permanente 'Mesa de Trabajo Intersectorial para la Gestión Migratoria'. The IDEHPUCP, with which the first author of this paper is affiliated, is a member of the coordination commission that brings together civil society institutions of the intersectoral working group for migration management. 
TIM) ${ }^{49}$ these are not related to one another and do not have procedures for the exchange of information. In addition, neither mechanism deals with cases of asylum, reflecting the previously mentioned dichotomy between refugees and other migrants and thereby undermining inter-institutional coordination between the Ministry of Foreign Affairs and MIGRACIONES. During the interviews for this paper, a UNHCR representative noted that 'the line of work on the subject of asylum seekers and refugees is understood to be disconnected from mobility issues. The complementarity that must exist between them has not yet been achieved. At the moment there is some awareness that the topic is complex and solutions are being developed, but these are still very young' (translation by the authors).

The interviews conducted with UNHCR, the Ministry of Foreign Affairs and the Ministry of the Interior confirmed that if, for example, the Ministry of Foreign Affairs attends to an asylum seeker, it does not generally consider whether the person may also be a victim of human trafficking and does not refer this person to the Ministry of the Interior. The same applies to the latter, which will not examine whether a victim of trafficking also has a potential claim for refugee status and should thus be referred to the competent authority dealing with such cases. These shortcomings are partly a function of inadequate training on aspects and categories of human mobility beyond their narrowly defined mandates, coupled with deficient structures for referrals to the appropriate institutions. ${ }^{50}$

Each of the above-mentioned institutions tends to focus solely on their particular mandates. This prevents a comprehensive analysis of migration as a complex process and, in some cases as in the two scenarios described above, the identification of individuals that potentially fall into more than one category at the same time.

49 Decreto Supremo N ${ }^{\circ}$ 001-2016-IN que aprueba el Reglamento de la Ley N ${ }^{\circ} 28950$, Ley contra la Trata de Personas y el Tráfico Ilícito de Migrantes, y crea la Comisión Multisectorial de naturaleza permanente contra la Trata de Personas y el Tráfico Il cito de Migrantes. IDEHPUCP is a guest member of this Commission.

50 C Blanco and C Marinelli, 'Victimas de Trata de Personas versus Migrantes en Situación Irregular. Retos y lineamientos para la atención y protección de las víctimas de trata de personas extranjeras en el Perú, Derecho PUCP, no. 78, 2017, pp. 173-198, p. 190. 


\section{Lack of regulations for policy implementation}

The Ministry of the Interior is currently drafting a protocol to provide guidance to MIGRACIONES and the police in dealing with cases of migrant smuggling. ${ }^{51}$ In this, it will be important to ensure that smuggled migrants can obtain residency in Peru, for example through the humanitarian or the special migration visas. ${ }^{52}$ In an interview conducted for this paper, Encuentros Jesuit Service of Solidarity pointed out that, at present, it is unclear whether the public prosecutor first needs to determine that there are sufficient grounds for assuming the crime of migrant smuggling has taken place before a migrant can be considered smuggled and access support. The protocol should therefore provide clear procedural guidance so that smuggled persons can gain access to the protection and assistance to which they are entitled.

Further, while there are various relevant frameworks in Peru for cases of foreign victims of human trafficking (laws, national plans and policies), the country lacks a specialised victim assistance framework for them and has no process for granting them residence status. ${ }^{53}$ MIGRACIONES has adopted a resolution to approve guidelines on how smuggled migrants and victims of trafficking from abroad may access the 'special migration visa" ${ }^{54}$ but these guidelines have not been published. According to a representative of the agency, the procedure to grant this type of visa requires 'self-identification' of a person and supporting documentation, for example a police report in alleged cases of human trafficking. Moreover, it remains unclear what progress has been made, if any, in the development of regulations operationalising the 'humanitarian migration visa'.

51 Ministry of the Interior, Sectoral Protocol on Migrant Smuggling (in process of being drafted by IDEHPUCP).

52 Blouin, p. 227.

53 Blanco and Marinelli, pp. 189-194.

54 Resolución de Superintendencia No. 0000357-2017-MIGRACIONES, Aprueban la Directiva 'Atención a Victimas de Trata de Personas y Tráfico Ilícito de Migrantes', 28 December 2017, retrieved 23 March 2018, http://busquedas.elperuano.pe/ normaslegales/aprueban-la-directiva-atencion-a-victimas-de-trata-de-persoresolucion-n-0000357-2017-migraciones-1602482-1/. 
MIGRACIONES also experiences difficulties in identifying foreign victims of trafficking in border areas, partly because they lack the necessary tools and protocols for such purposes. A representative of the agency highlighted in our interview that in the few cases of this type that they have dealt with, the victims were referred to them by other institutions. Meeting reports of MIGRACIONES note that, at times, their officials encounter individuals that they suspect may have been trafficked, but the agents can only respond by notifying the police, which sometimes appears reluctant to take action. ${ }^{55}$ It is worth exploring whether perceptions of the 'typical' victim being Peruvian, not a foreigner, may lead authorities to more frequently identify foreigners as irregular migrants rather than trafficked persons. ${ }^{56}$

The fact that victims of human trafficking often remain unidentified due to the reasons mentioned above also has direct repercussions for the work of some international organisations. For example, in our focus group discussion, an IOM representative explained that, in order for the agency to assist victims of human trafficking, the state first needs to recognise the person as such after a police report is filed and a criminal investigation opened. However, if the trafficked person does not file a police report, IOM cannot provide services and for this reason the number of victims that are able to access IOM's assistance programme for trafficked persons is very small. ${ }^{57}$

\section{Conclusion}

It is challenging to examine migratory categories while patterns of human mobility are shifting and the relevant regulatory framework is undergoing reform. Such is the case in Peru where difficulties are further compounded by overlaps in the mandates of, and a lack of coordination between, relevant institutions. However, the new realities of migration in the country compel us, more urgently than ever before, to rethink these migrant categories from a holistic perspective and propose comprehensive responses that protect and guarantee the rights of migrants.

55 This was an internal meeting inside MIGRACIONES in November 2017.

56 C Blanco and Marinelli, p. 190.

${ }^{57}$ E Button, A Jáuregui and F Mamani, Informe Trata de Personas en América Latina y El Caribe $165^{\circ}$ Período de Sesiones Comisión Interamericana de Derechos Humanos, IDEHPUCP, Lima, 2017. 
One proposal that arises from our analysis is the need for a truly intersectoral approach to human mobility among the different institutions-one that allows the categories to be understood in an integral way. Another key measure is to develop protocols to operationalise the standards and plans that have already been adopted. Without these interventions, it will be impossible to respond to the various needs of migrants, be they victims of human trafficking, smuggled migrants or others requiring protection.

Cécile Blouin is a senior researcher at the Institute for Democracy and Human Rights at the Pontifical Catholic University of Peru (IDEHPUCP) and teacher at the Faculty of Law and the Human Rights Master Degree at PUCP. She previously worked as consultant for the Office of the United Nations High Commissioner for Refugees. Her research interests include migration and human rights, intersectionality and gender in migration, forced migration, and trafficking and smuggling in Latin America, especially Peru. Email: cblouin@pucp.edu.pe.

Emily Button received her Juris Doctorate from Rutgers Law School, USA. She is an independent researcher focusing on human mobility issues in Latin America, particularly the trafficking of persons and the rights of refugees and other vulnerable populations in the context of migration. Most recently, she was a researcher at the IDEHPUCP. Email emilyannbutton@gmail.com. 